\title{
SIMULATION OF A THUNDERSTORM EVENT OVER BANGLADESH USING WRF-ARW MODEL
}

\author{
M. N. Ahasan ${ }^{\text {* }}$, D. A. Quadir ${ }^{2}$, K.A. Khan ${ }^{3}$ and M. S. Haque ${ }^{4}$ \\ ${ }^{1}$ SAARC Meteorological Research Centre (SMRC), Dhaka, Bangladesh \\ ${ }^{2}$ Department of Physics, Uttara University, Dhaka, Bangladesh \\ ${ }^{3}$ Department of Physics, Jagannath University, Dhaka, Bangladesh \\ ${ }^{4}$ Department of Physics, Melandah Govt. College, Jamalpur, Bangladesh \\ *Corresponding e-mail: nazmul_smre@yahoo.com
}

\begin{abstract}
Numerical simulation of the thunderstorm event occurred over Srimangal, Bangladesh at 1200 UTC on 21 May 2011 have been carried out using Advance Research dynamic core of Weather Research and Forecasting Model (WRF-ARW). The WRF model was run in a domain at $9 \mathrm{~km}$ horizontal resolution using six hourly NCEP-FNL datasets from 0000UTC of 21 May to 0000UTC of 22 May 2011 as initial and boundary conditions. Hourly outputs have been analyzed to asses and/or compare the model performance. The WRF model captured the studied thunderstorm event on 21 May 2011 in reasonably well with some spatial and temporal biases in the results. But the model simulated 24-h rainfall over the country as a whole overestimated the rainfall by $46.72 \%$ compared to that of Bangladesh Meteorological Department (BMD) observation.
\end{abstract}

Key words: Simulation, Thunderstorm, WRF-ARW, NCEP-FNL, Rainfall

\section{INTRODUCTION}

Bangladesh (latitudes $20^{\circ} 34^{\prime}-26^{\circ} 38^{\prime} \mathrm{N}$ and longitudes $\left.88^{\circ} 01^{\prime}-92^{\circ} 41^{\prime} \mathrm{E}\right)$ experiences a high frequency of thunderstorms during the pre-monsoon period which have a great destructive potential and characterized by tornadic violence, often accompanied with high magnitude squalls, torrential rains and hails. They cause an extensive damage to life and property in the areas through which they traverse. The seat of formation of the thunderstorms, which visit Bangladesh, may be either locally within Bangladesh or they may get regenerated as the downstream propagation of the thunderstorms developing further north over Sub-Himalayan West Bengal \& Sikkim, Assam valley, the plateau of Meghalaya, or to the west in the neighbouring West Bengal and even over the plateau of Jharkhand in India. These storms are designated as Nor'westers in this region, so called because the storm usually approaches a station from a northwesterly direction. These are also locally known as 'Kalbaishakhi' in Bengali because of the heavy damage to life and property inflicted by them during the month of Baishakh, the first month of Bengali calendar. Some of the severe thunderstorms develop into tornadoes.

Several wide spread thunderstorms occurred over Bangladesh on 21 May 2011. The convection persisted over different parts of Bangladesh from 1200 UTC to 1800 UTC. The Meteosat cloud images on 21 May 2011 are shown in Fig.1(a-b). The dense convective clouds are observed over Bangladesh and neighbourhood at 1200 and 1800 UTC. The observed 24-h accumulated rainfall at different stations of Bangladesh on 21 May 2011 is shown in Table-1. It is depicted that there are several thunderstorm events occurred over different parts of the country on 21 May 2011. However, among the thunderstorms occurred on 21 May, 2011 over different parts of the country, the event occurred over Srimangal, Bangladesh at 1200 UTC was prominent and observed rainfall was $88 \mathrm{~mm}$. Thus, the thunderstorm event occurred over Srimangal, Bangladeshat 1200 UTC on 21 May, 2011 has been highlighted in this paper.
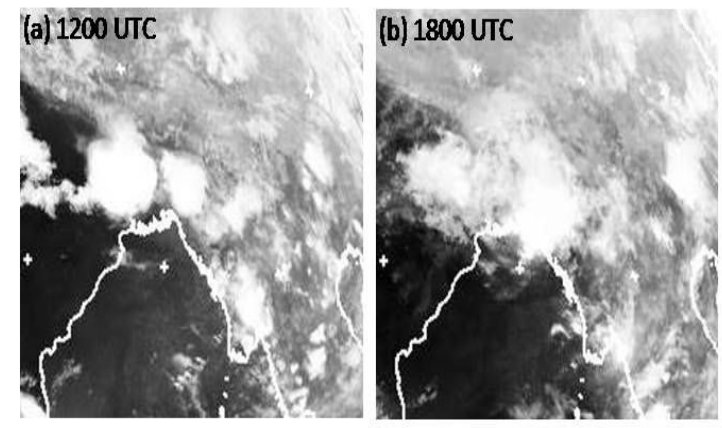

Figure 1. Meteosat cloud images at (a) 1200 UTC and (b) 1800 UTC on 21 May 2011.

Table 1. The observed 24-h accumulated rainfall at different stations of Bangladesh on 21 May 2011

(Bangladesh Meteorological Department).

\begin{tabular}{|c|c|}
\hline Station Name & Observed Rainfall \\
\hline Chittagong $\left(22.27^{\circ} \mathrm{N}, 91.82^{\circ} \mathrm{E}\right)$ & 65 \\
\hline Cox's Bazar $\left(21.43^{\circ} \mathrm{N}, 91.98^{\circ} \mathrm{E}\right)$ & 54 \\
\hline Feni $\left(23.03^{\circ} \mathrm{N}, 91.42^{\circ} \mathrm{E}\right)$ & 46 \\
\hline Kutubdia $\left(21.82^{\circ} \mathrm{N}, 91.85^{\circ} \mathrm{E}\right)$ & 46 \\
\hline Srimangal $\left(24.30^{\circ} \mathrm{N}, 91.73^{\circ} \mathrm{E}\right)$ & $\mathbf{8 8}$ \\
\hline Sitakunda $\left(22.63^{\circ} \mathrm{N}, 91.70^{\circ} \mathrm{E}\right)$ & 74 \\
\hline
\end{tabular}

This particular case of thunderstorm over Srimangal, Bangladesh on 21 May 2011 has been selected to carry out the present study using Advance 
Research dynamic core of Weather Research and Forecasting Model (thereafter WRF-ARW) version 3.5.1. Application of Numerical Weather Prediction (NWP) model in research and forecasting of thunderstorms during premonsoon season is few in Bangladesh. However, some works have been done about synoptic situation and composite characteristics of severe thunderstorms including tornadoes during premonsoon season over Bangladesh using FSU, MM5 and WRF model by Prasad, 2006 ; Basnayake et al., 2010 $0^{2}$, Akter and Islam, 2007, $2009^{4}$, Ahasan et al., 2010 , 2013 ${ }^{6}$ and Das, 20097, 2010 and SAARC-STORM, 2011 $1^{9}, 2013^{10}$ etc. Most of the above studies have been carried out using FSU and MM5 model which are not using by the meteorological community now days. Though some of the above works have been carried out using WRF model, the causes and mechanisms of the selected thunderstorm events are not described properly and need to refine the results by further study.

The primary objective of this study is to simulate the thunderstorm event over Srimangal, Bangladesh on 21 May 2011 over Bangladesh using WRF-ARW model version 3.5.1. The secondary objective is to identify and document the possible causes and mechanisms of the selected thunderstorm event.

\section{MODEL DESCRIPTION}

This section provides a brief introduction about the WRF-ARW model, data used and the methodology incorporated to simulate and to analysis the selected thunderstorm event.

\section{Model introduction}

The WRF Model is a new-generation mesoscale NWP system designed to serve both operational forecasting and atmospheric research needs. It features multiple dynamical cores, a 3-Dimensional Variational (3DVar) data assimilation system, and a software architecture allowing for computational parallelism and system extensibility ${ }^{11}$. WRF is suitable for a broad spectrum of applications across scales ranging from meters to thousands of kilometers. Applications of WRF include research and operational NWP, data assimilation and parameterized-physics research, downscaling climate simulations, driving air quality models, atmosphereocean coupling, and idealized simulations (i.e., boundary-layer eddies, convection, baroclinic waves). There are two dynamics solvers in the WRF system: the Advanced Research WRF (ARW) solver (originally referred to as the Eulerian mass or "em") developed primarily at NCAR, and the Nonhydrostatic Mesoscale Model (NMM) solver developed at NCEP. The ARW system consists of the ARW dynamics solver with other components of the WRF system needed to produce a simulation. The WRF-ARW (Version 3.5.1) has been implemented during the present study.

\section{Model Experimental Setup}

The WRF model is run on a single domain at $9 \mathrm{~km}$ horizontal resolution. The domain size is taken $124 \times 103 \mathrm{~km}$. The domain is centered $\left(23^{\circ} \mathrm{N}, 90^{\circ} \mathrm{E}\right)$ over Bangladesh to represent the regional-scale circulations and to solve the complex flows of this region. The domain of WRF model for the NWP study with the topography in background is shown in Fig.2. There are 28 vertical layers. The model is run using the Kain-Fritsch (new Eta) scheme for cumulus parameterization $^{12}$, Yonsei University (YSU) scheme for the boundary layer parameterization ${ }^{13}$, WSM 6 class graupel schemes for microphysics ${ }^{14}$ and Rapid Radiative Transfer Model (RRTM) for longwave ${ }^{15}$ and Dudhia for short wave radiation scheme ${ }^{16}$ for the selected case. The physics and dynamics employed in the model for the present study are summarized in Table-2. The initial condition of the model simulation is taken as 0000 UTC of 21 May 2011 and lateral boundary condition is taken for 24 hours.

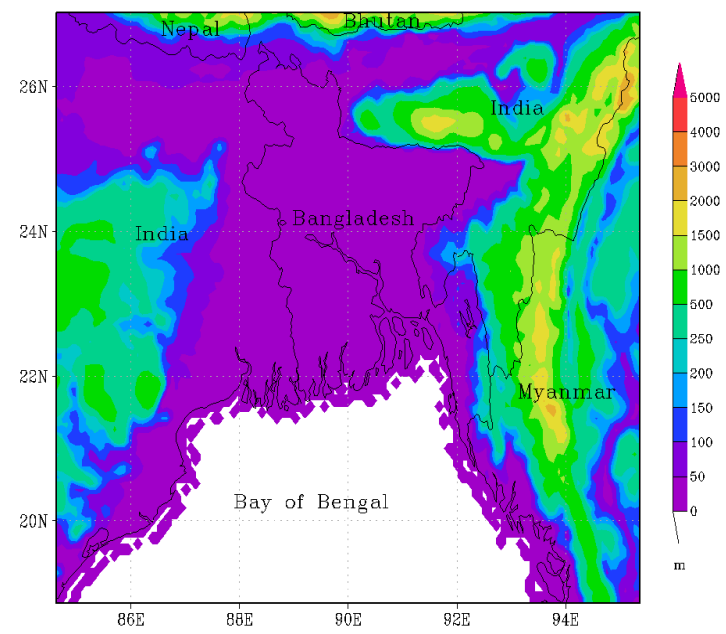

Figure 2. WRF Model domain for NWP study (Topography of the domain in the background are shaded).

\section{Data Used}

The United States Geological Survey (USGS) Global datasets with $30 \mathrm{sec}$ horizontal resolution were used to create terrain/topography and vegetation/landuse field. The Final (FNL) Operational Model Global Tropospheric Analyses of National Centre for Environmental Prediction (NCEP) with the $1^{\circ} \times 1^{\circ}$ horizontal and 6-h temporal resolution were used as the initial and lateral boundary condition.

The daily observed rainfall data have been collected from the archive of Bangladesh Meteorological Department (BMD) to compare or validate the model derived rainfall. The Meteosat cloud images are also used to see the signature of convective activities and moisture presence over the study area. 
Table 2. Physics and dynamics used in the WRF Model

\begin{tabular}{|c|c|}
\hline \multicolumn{2}{|r|}{ Physics } \\
\hline Convection & Kain-Fritsch (new Eta) ${ }^{12}$ \\
\hline PBL & YSU Scheme ${ }^{13}$ \\
\hline Surface Layer Option & Monin-Obukhovsheme \\
\hline Cloud Microphysics & WSM 6-Class graupel schemes ${ }^{14}$ \\
\hline Radiation & $\begin{array}{l}\text { Rapid Radiative Transfer Model (RRTM) }{ }^{15} \text { for long wave and } \\
\text { Dudhia }{ }^{16} \text { for short wave }\end{array}$ \\
\hline Land Surface Processes & Unified Noah Land Surface Model \\
\hline \multicolumn{2}{|r|}{ Dynamics } \\
\hline Time Integration & 3rd order Runge-Kutta \\
\hline $\begin{array}{l}\text { Vertical Differencing } \\
\text { Time Filtering }\end{array}$ & $\begin{array}{c}\text { Arakawa's Energy Conserving Scheme } \\
\text { Robert's Method }\end{array}$ \\
\hline Horizontal Diffusion & 2nd order over Quasi-pressure, surface, scale selective \\
\hline Spatial difference scheme & 6th order centered difference \\
\hline Horizontal grid & Arakawa C-grid \\
\hline
\end{tabular}

\section{Methodology}

The WRF-ARW Model developed by NCARNCEP, USA has been used for the study of the selected thunderstorm occurred over Srimangal, Bangladesh on 21 May 2011 over Bangladesh. Model was run using six hourly NCEP-FNL datasets from 0000UTC of 21 May to 0000UTC of 22 May 2011 as initial and boundary condition. The model outputs help to investigate the causes and mechanisms for the formation of the thunderstorm event. Hourly outputs have been analyzed to compare and/or asses the model performance. The mean sea level pressure; low level and upper level wind flow; horizontal and vertical profile of moisture flux; low level relative vorticity, low level vertical wind shear of the $u$ component of wind; convective available potential energy, convective inhibition energy, outgoing long wave radiation and rainfall etc fields have been investigated. The thunderstorm become mature stage and passed through the northeast region (i.e., Srimangal) of the country at about 1200 UTC as per BMD observation. Thus all model parameters are prepared for the 1200UTC (during mature time of thunderstorm event) of 21 May, 2011. Model simulated total convective (Cumulus scheme) and non-convective (Grid scale) precipitation at surface level has been considered as rainfall throughout the study. Observed daily rainfall data of BMD has been used to validate / compare the model simulated rainfall. Both spatial and temporal comparison methods have been used to compare the model simulated rainfall with observed rainfall.

\section{RESULTS AND DISCUSSION}

The results and discussion of the study are described in details below:

\section{Mean Sea Level Pressure}

The spatial distribution of mean sea level pressure $(\mathrm{hPa})$ along with low level $(950 \mathrm{hPa})$ winds valid at 1200 UTC of 21 May, 2011 is shown in Fig.3. It is found that an active elongated trough of low pressure over the Gangetic plains of India which intrude towards Bangladesh through middle of the country.
The lowest surface pressure in the centre of the trough is about $996 \mathrm{hPa}$ which is very low during this season. The formation of low pressure area over the Gangetic plains and intrude towards Bangladesh is the very common characteristics for the development of convective activities over the country.

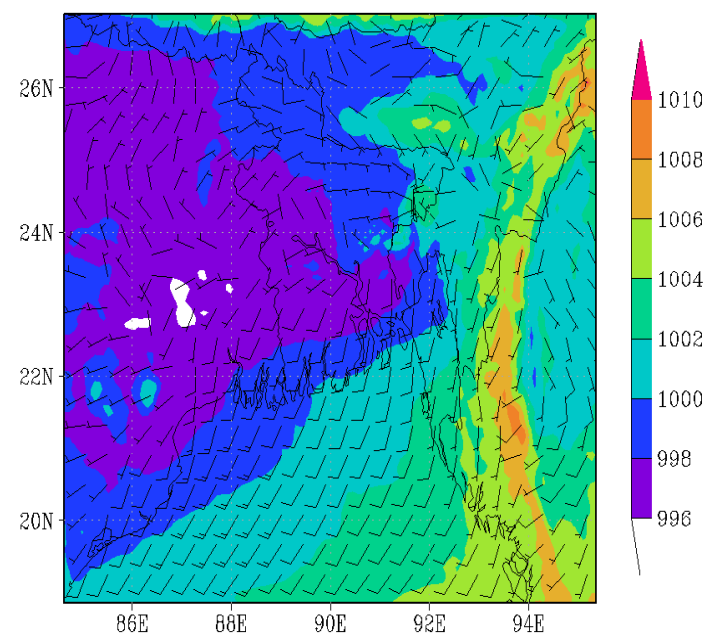

Figure 3. Mean sea level pressure $(\mathrm{hPa})$ along with low level $(950 \mathrm{hPa})$ winds valid at $1200 \mathrm{UTC}$ on 21 May 2011.

\section{Low Level Winds}

The distribution of low level $(925 \mathrm{hPa})$ wind flow $\left(\mathrm{ms}^{-1}\right)$ valid at1200 UTC of 21 May 2011 is presented in Fig. 4. The prominent feature is strong southwesterly/southerly low level jet (LLJ) transporting moisture from the Bay of Bengal into Bangladesh at 1200 UTC of 21 May 2011. These low level winds converged over the narrow belt of Bangladesh from large area of the Bay of Bengal, helps for moisture incursion and to develop severe convective activity over Bangladesh. The formation of dry line (meeting line of cold dry air and warm moist air together) over the central part of the country is clearly seen in the wind chart. Usually thunderstorm forms over the southern side of this dry line. 


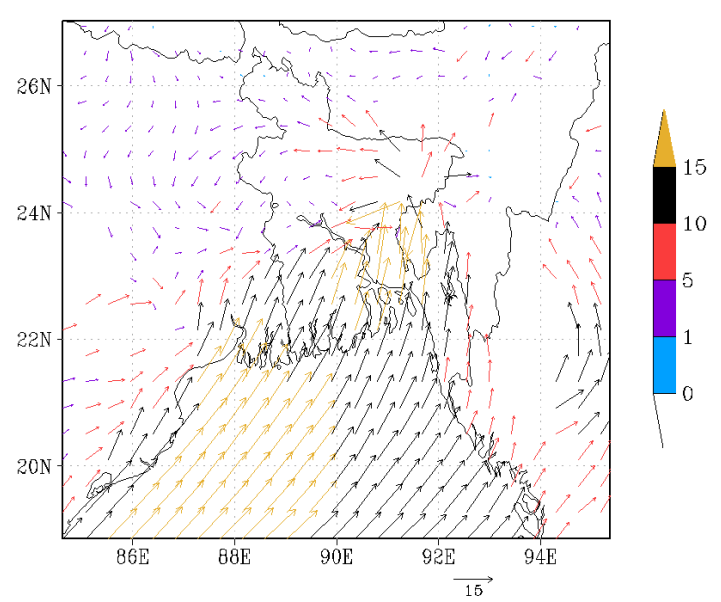

Figure 4. Distribution of low level $(925 \mathrm{hPa})$ wind flow $\left(\mathrm{ms}^{-1}\right)$ valid at 1200 UTC of 21 May 2011.

\section{Upper Level Winds}

The distribution of upper level $(300 \mathrm{hPa})$ wind flow $\left(\mathrm{ms}^{-1}\right)$ valid at 1200 UTC of 21 May 2011 representing the subtropical jet stream over the region is shown in Fig.5. A jet stream in the order of $20 \mathrm{~ms}^{-1}$ may be seen over Bangladesh at 1200 UTC of 21 May, 2011, marking a strong vertical wind shear in the environment. The presence of subtropical jet stream at upper level provides a mechanism for strong vertical wind shear, thus favouring development of severe convection. The speed of subtropical jet stream $\left(20 \mathrm{~ms}^{-1}\right)$ has been found to contribute to the severity of the thunderstorms.

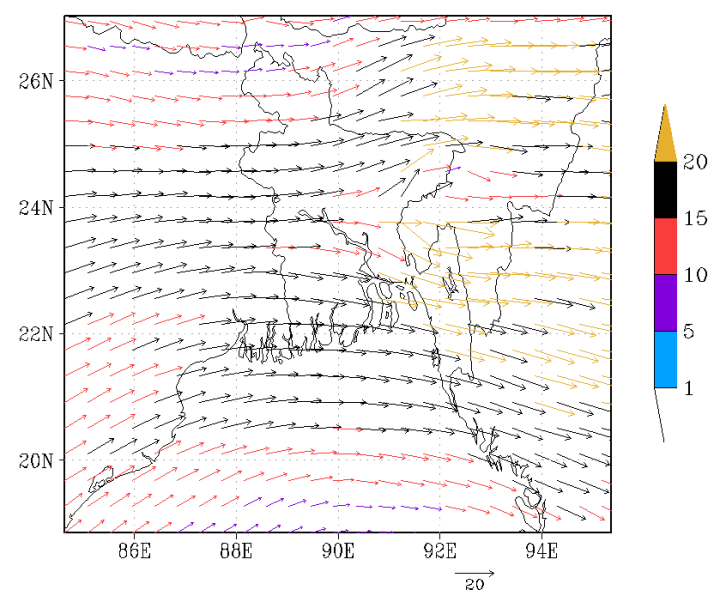

Figure 5. Distribution of upper level $(300 \mathrm{hPa})$ wind flow $\left(\mathrm{ms}^{-1}\right)$ valid at1200 UTC of 21 May 2011.

\section{Vertical Wind Shear}

The spatial distribution of vertical wind shear $\left(\mathrm{ms}^{-1}\right)$ of the $\mathrm{u}$ component of wind in the lowest $6 \mathrm{~km}$ of the atmosphere between 500 and $950 \mathrm{hPa}$ valid at1200 UTC of 21 May 2011 is presented in Fig.6. The prominent feature is the core of strong vertical wind shear of the order of 15-20 ms ${ }^{-1}$ ( 29-3 knots) may be seen over Bangladesh and nearby territory of India. This vertical wind shear (15-20 $\left.\mathrm{ms}^{-1}\right)$ may helped to develop multicell thunderstorm (multicells lines) over the region ${ }^{17}$.

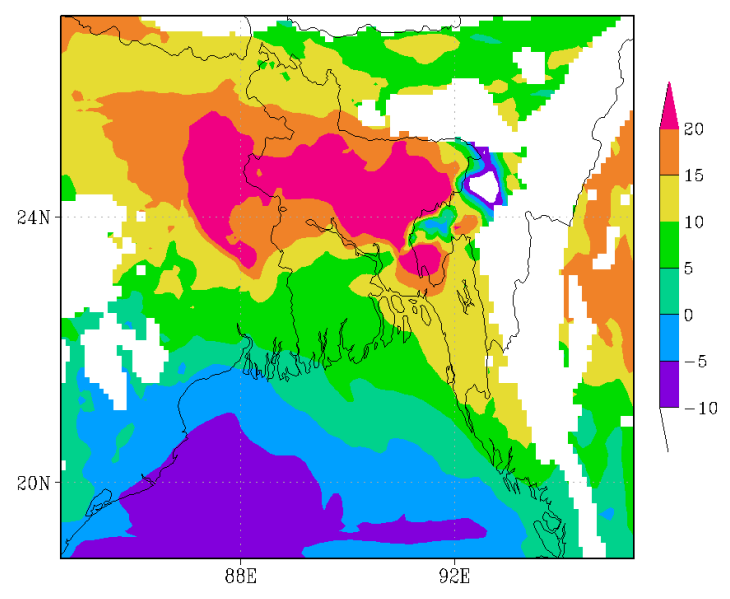

Figure 6. Vertical wind shear $\left(\mathrm{ms}^{-1}\right)$ of the $\mathrm{u}$ component of wind in the lowest $6 \mathrm{~km}$ of the atmosphere between 500 and $950 \mathrm{hPa}$ valid at1200 UTC on 21 May 2011.

\section{Relative Humidity / Moisture}

The distribution of low level $(950 \mathrm{hPa})$ relative humidity (\%) valid at 0900 UTC (3-hrs before the event over Srimangal) of 21 May 2011 is presented in Fig.7(a). It is found that the contents of moisture of the order of $80-90 \%$ over most of the eastern and northern parts of Bangladesh and 70-80\% over rest of the part of Bangladesh at 0900 UTC of 21 May, 2011. The circulation of southerly/southwesterly LLJ [Fig.4] transports required moisture from the Bay of Bengal to the plains of Bangladesh and the adjoining states of India. The vertical profile of the relative humidity valid at1200 UTC of 21 May 2011 along $24.30^{\circ}$ latitude (latitudinal position of Srimangal) is presented in Fig.7(b). It is found that the intensity of vertical profile of the relative humidity field reached upto the top of troposphere at 1200 UTC of 21 May, 2011 in the mature stage along $91.50^{\circ}-92.50^{\circ} \mathrm{E}$ (the position of Srimangal) longitude [Fig.7(b)]. The updraft and downdraft are clearly seen in the vertical profile of moisture. The envil shape of the thunderstorm at the mature stage is also clearly seen in the moisture profile [Fig.7(b)]. 

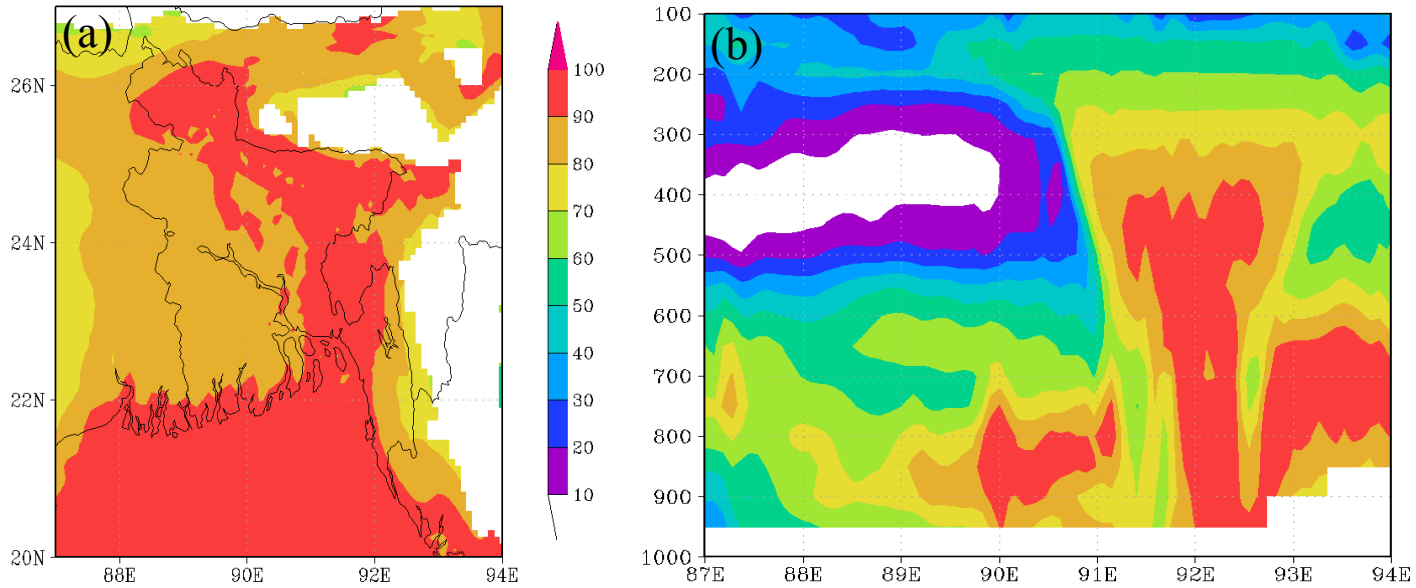

Figure 7. Distribution of low level $(950 \mathrm{hPa})$ relative humidity (\%) valid at 0900 UTC (3-hrs before the event) of 21 May 2011 (a) and vertical profile of relative humidity (\%) along with $24.30^{\circ} \mathrm{N}$ latitude (latitudinal position of Srimangal) valid at 1200 UTC (mature stage of thunderstorm) of 21 May 2011 (b).

\section{Low Level Relative Vorticity}

The spatial distribution of low level $(925 \mathrm{hPa})$ relative vorticity $\left(\times 10^{-5} \mathrm{~s}^{-1}\right)$ valid at1200 UTC of 21 May 2011 is presented in Fig.8. The prominent feature is a core of vorticity maxima of the order of $10-20 \times 10^{-5} \mathrm{~s}^{-1}$ may be seen over the northeastern part of the country at 1200 UTC. The values of low level relative vorticites play an important role to develop convective activities.

\section{Convective Available Potential Energy (CAPE) \& Convective Inhibition Energy (CINE)}

The spatial distribution of CAPE and CINE valid at1200 UTC of 21 May 2011 are presented in Fig.9(ab). In Fig. 9(a), it is found that a tongue of CAPE reached upto the northeast region of covering Srimangal in the order of $2000 \mathrm{JKg}^{-1}$ which helps to develop severe convective activities over the region. On the otherhand, in Fig. 9(b), it is found that the most of the part of Bangladesh and nearby territory of India is characterized by low CINE of the order of 0 $\mathrm{JKg}^{-1}$. A combination of high CAPE and low CINE would render the environment thermodynamically favourable for convection.

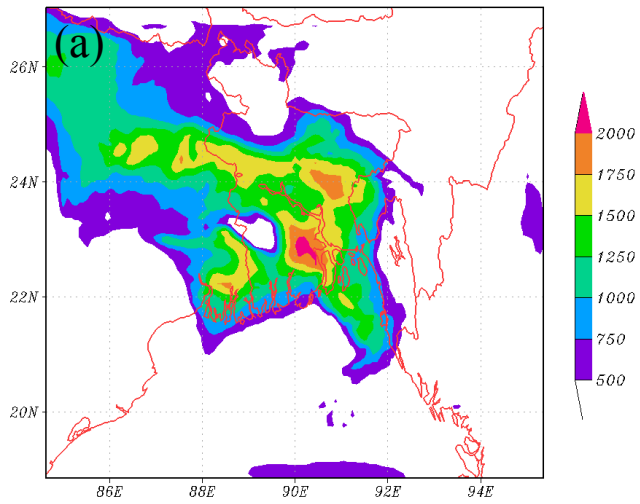

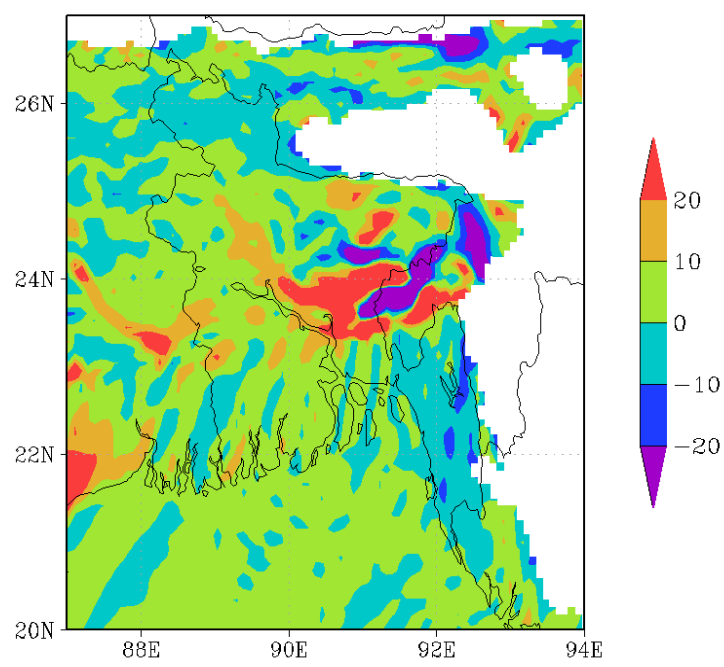

Figure 8. Low level $(925 \mathrm{hPa})$ relative vorticity $\left(\mathrm{x} 10^{-5} \mathrm{~s}^{-1}\right)$ valid at $1200 \mathrm{UTC}$ of 21 May 2011.

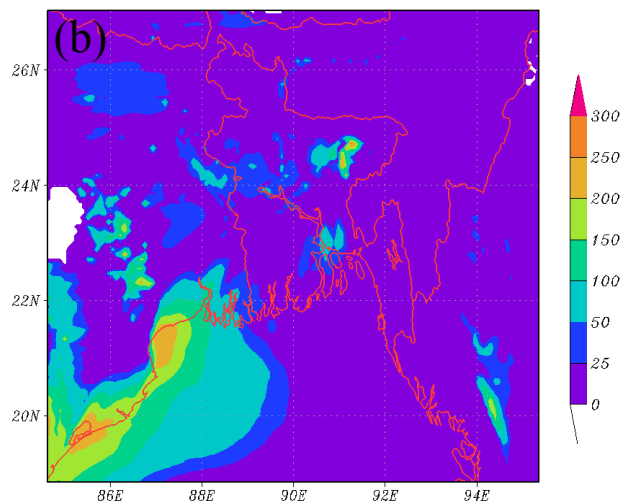

Figure 9. Convective available potential energy (CAPE) and Convective inhibition energy (CINE) valid at1200 UTC of 21 May 2011.

Journal of Mechanical Engineering, Vol. ME 44, No. 2, December 2014

Transaction of the Mechanical Engineering Division, The Institute of Engineers, Bangladesh 


\section{Outgoing Longwave Radiation (OLR)}

The distribution of model derived OLR valid at 1200 UTC of 21 May 2011 is presented in Fig. 10.It is found that the northeastern part of Bangladesh including the part of Srimangal is covered by the low OLR of the order of 50-100 $\mathrm{Wm}^{-2}$ which indicated that the area was covered by high densely convective cloud.

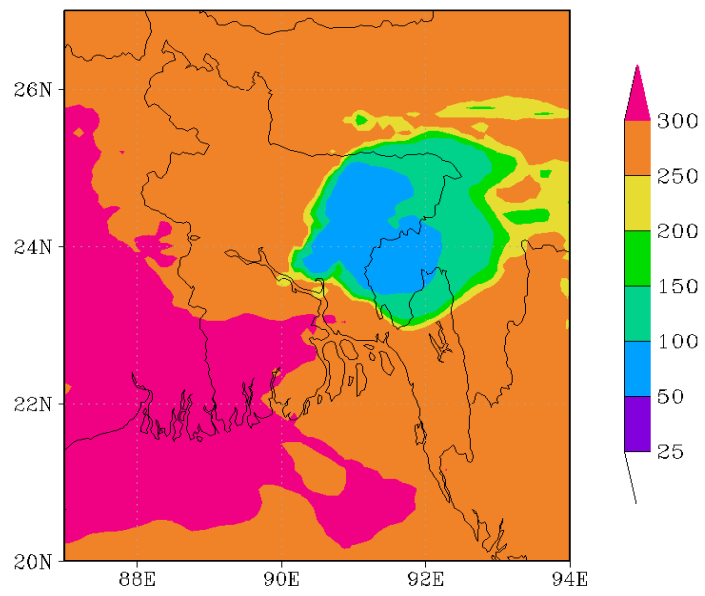

Figure 10. Distribution of Outgoing Longwave Radiation (OLR) valid at1200 UTC of 21 May 2011.

\section{Rainfall Analysis}

The 24-h accumulated model simulated and BMD observed rainfall valid for 0000 UTC of 22 May 2011

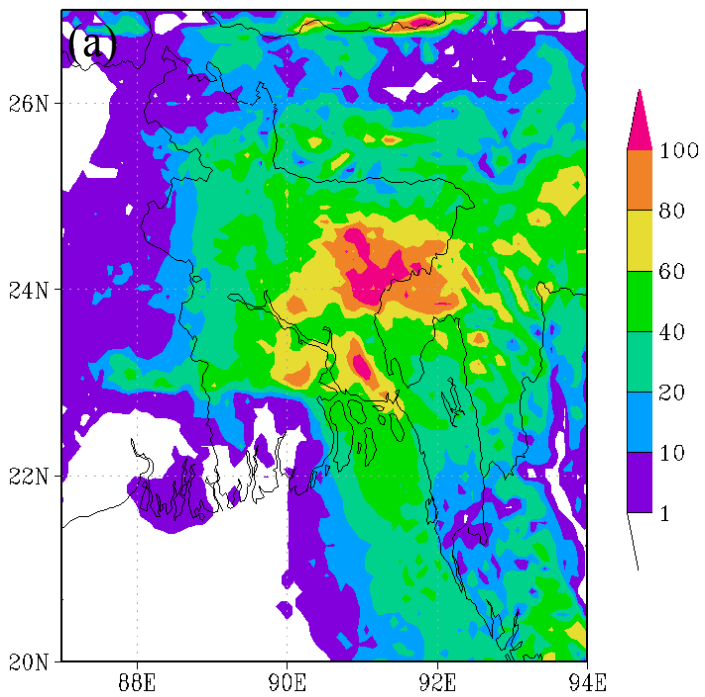

is shown in Fig. 11(a-b). It is found that the model captured the location of the rainfall as compared with BMD observations in reasonably well. The 24-h accumulated rainfall pattern is almost same in model simulation (a) and BMD observation (b). However, the intensity of model simulated rainfall is slightly higher and the area coverage of model simulated rainfall is slightly broader than that of BMD observation. In quantitative comparison, country as a whole, it is found that the model simulated rainfall fairly overestimated $(46.72 \%)$ the BMD observed rainfall. It is also found that the model simulated rainfall is spatially deviated by about $\sim 25-50 \mathrm{~km}$ in respect of BMD observation.

The network of the observation stations over Bangladesh is not too dense enough to measure this highly localized thunderstorm event. There are very few observatory over the northeast part of Bangladesh where model simulated highest rainfall [Fig.11(b)] and the thunderstorm occurred on 21 May, 2011. The highest observed rainfall is about $88 \mathrm{~mm}$ at Srimangal of Bangladesh, whereas model simulated rainfall is about $\sim 96.52 \mathrm{~mm}$ which is $9.68 \%$ higher than observed rainfall. It is found that the WRF-ARW model slightly overestimated the premonsoon rainfall over Bangladesh. Thus the WRF-ARW model simulated rainfall seems to be realistic though there are spatial and temporal biases in the simulated rainfall pattern. The signature of the dense convective cloud is also seen in the Meteosat cloud images at 1200 UTC of 21 May 2011 [Fig.1(a)].

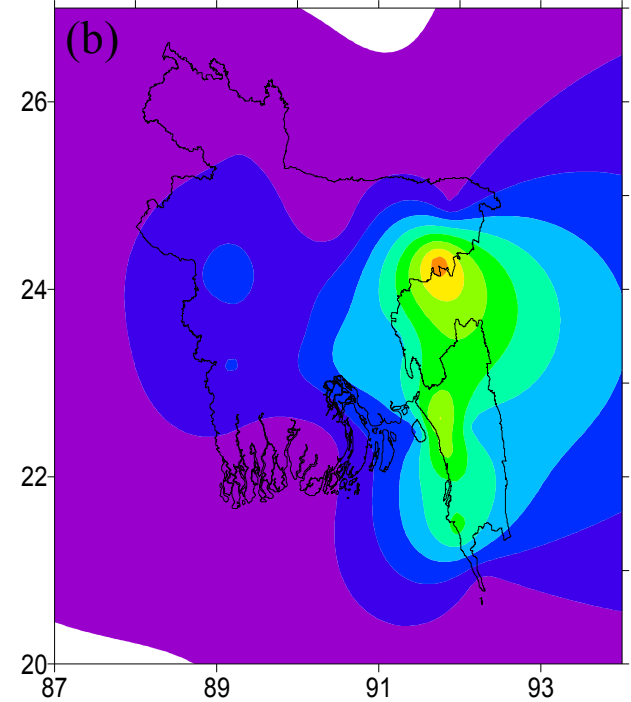

Figure 11. The 24-h accumulate (a) model simulated and (b) BMD observed rainfall valid for 0000 UTC of 22 May 2011. 


\section{CONCLUSIONS}

On the basis of the present study, the following conclusions can be drawn:

1. The WRF model captured the studied thunderstorm event on 21 May 2011 in reasonably well though there are some spatial and temporal biases in the model simulation. Mean sea level pressure contain an elongated trough of low pressure running across the Gangetic plains over north India which intrudes Bangladesh through the middle of the western part of the country. The lowest surface pressure at the centre of the low pressure is about $996 \mathrm{hPa}$.

2. The distribution of low level $(925 \mathrm{hPa})$ wind flow shows that a strong southwesterly/southerly low level jet (LLJ) of the order of $\sim 15 \mathrm{~ms}^{-1}$ whichconverged over the narrow belt of Bangladesh from large area of the Bay of Bengal, helps for moisture incursion and to develop severe convective activity over Bangladesh. The formation of dry line (meeting line of cold dry air and warm moist air together) over the central part of the country is clearly seen in the wind chart.

3. A subtropical jet stream at $300 \mathrm{hPa}$ wind flow in the order of $20 \mathrm{~ms}^{-1}$ may be seen over Bangladesh at 1200 UTC of 21 May, 2011, marking a strong vertical wind shear in the environment. The presence of subtropical jet stream at upper level provides a mechanism for strong vertical wind shear, thus favouring development of severe convection.

4. The spatial distribution of vertical wind shear $\left(\mathrm{ms}^{-1}\right)$ of the u component of wind in the lowest $6 \mathrm{~km}$ of the atmosphere between 500 and $950 \mathrm{hPa}$ valid at 1200 UTC of 21 May 2011 shows that the core of strong vertical wind shear of the order of 15-20 ms ${ }^{-1}$ ( 29-39 knots) may be seen over Bangladesh and nearby territory of India. This vertical wind shear (15-20 ms $\left.{ }^{1}\right)$ may helped to develop multicell thunderstorm (multicells lines) over the region.

5. A strong southerly/southwesterly low level jet $(\sim 15$ $\mathrm{ms}^{-1}$ ) transporting moisture of the order of $70-90 \%$ from vast area of the Bay of Bengal towards the narrow zone (eastern and northern part) of Bangladesh which vertically reached up to the top of the toposphere in the mature stage along $91.50^{\circ}$ $92.50^{\circ} \mathrm{E}$ longitude (the position of Srimangal). Model simulated the dry line, updraft, downdraft and envil shape at the mature of the thunderstorm in reseaonably well.

6.The area of Srimangal where thunderstorm occurred are characterized by the high value of low level $(925$ $\mathrm{hPa}$ ) relative vorticityof the order of $10-20 \times 10^{-5} \mathrm{~s}^{-1}$, very low value of the OLR of the order of 50-100 $\mathrm{Wm}^{-2}$. The combination of high value of CAPE of the order of $2000 \mathrm{JKg}^{-1}$ and low value of CINE of the order of $0 \mathrm{JKg}^{-1}$ makes the northeastern area of Bangladesh favourable for the occurrence of the thunderstorm.
7. The WRF model captured the location and structure of the rainfall over northeast part of the country and its neighbourhoods in reasonably well. But the model simulated 24-h rainfall over the country overestimated the rainfall compared to that of BMD Observation.

Finally, it is concluded that the WRF-ARW model version 3.5.1 may be adopted in study of research and prediction of the thunderstorms during premonsoon season over Bangladesh, but it needs to do more case study.

\section{ACKNOWLEDGEMENTS}

The authors are thankful to NCAR, MMM for providing the WRF model source code, and necessary support to run and executive the model. The authors are also thankful to USGS and NCEP for providing the topography/landuse and I\&LBC data to run the model. Thanks are due to Director, BMD and SMRC for providing the necessary data and constant support during this study.

\section{REFERENCES}

1. K. Prasad, 2006, "Environment and synoptic conditions associated with Nor'westers and Tornadoes in Bangladesh: An appraisal based on Numerical Weather Prediction (NWP) guidance products", SAARC Meteorological Research Centre (SMRC), SMRC Scientific Report, 14, 87 pp.

2. B. R. S. B. Basnayake, M. K Das, F. F. Nessa, and M. M. Rahman, 2010, "Nor'westers over Bangladesh and neighbourhood during pre-monsoon season of 2009: Observations and WRF model simulation", SMRC Scientific Report, 36, 61 pp

3. N. Akter and M. N. Islam, 2007, "Use of MM5 model for weather forecasting over Bangladesh region", BRAC University Journal, 4(1), 75-79

4. N. Akter and M. N. Islam, 2009, "Employment of MM5 in simulating MCSs developed in and around Bangladesh, Mausam, 60(2), 137-146

5. M. N. Ahasan, M. N Islam, and N. Ferdousi, 2010, "A diagnostic study on synoptic and environmental conditions associated with Nor'westers in and around Bangladesh using MM5 model", Proceedings of the SAARC Seminar on Nor'westers and Tornadoes over the SAARC Region and their Forecasting \& Preparedness, 20-21 August, 2008, Dhaka, Bangladesh, 143-156

6. M. N. Ahasan and S. K. Debsarma, 2014: Impact of data assimilation in simulation of thunderstorm (Squall line) event over Bangladesh using WRF model, during SAARC STORM Pilot Field Experiment 2011, Natural Hazards, Springer Netherlands, In Press, DOI: 10.1007/s11069-0141369-Z

7. S. Das, 2009, "Composite characteristics of Nor'Westers observed by TRMM \& simulated by WRF Model, SAARC Meteorological Research Centre (SMRC), SMRC Scientific Report, 25, 47 pp 8. S. Das, 2010, "Climatology of Thunderstorms over the SAARC Region", SAARC Meteorological 
Research Centre (SMRC).SMRC Scientific Report, 35, $73 \mathrm{pp}$

9. SAARC-STORM, 2013, "SAARC STORM Pilot Field Experiment 2011, SAARC Meteorological Research Centre (SMRC)", SMRC Scientific Report, 46, $51 \mathrm{pp}$

10. SAARC-STORM, 2011, "SAARC STORM Pilot Field Experiment 2010, SAARC Meteorological Research Centre (SMRC)", SMRC Scientific Report, $40,54 \mathrm{pp}$

11. W. C. Skamarock, J. B. Klemp, J, Dudhia, D. O. Gill, D. M. Barker, M. G. Duda, X. Y. Huang, W. Wang, and J. G. Powers, 2008, “A Description of the Advanced Research WRF Version 3", Mesoscale and Microscale Meteorology Division, National Center for Atmospheric Research, Boulder, Colorado, USA, NCAR TECHNICAL NOTE, NCAR/TN-475+STR, June 2008, 113 pp.

12. J. S. Kain, 2004, "The Kain-Fritsch Convective Parameterization: An Update”, J. Appl. Meteor., 43, 170-181
13. Y. S. Hong, J. Y. Noh and J. Dudhia, 2006, “A new vertical diffusion package with an explicit treatment of entrainment process", Mon. Wea. Rev., 134, 2318-2341

14. Y. S. Hong, and J. Lim, 2006, "The WRF SingleMoment 6-Class Microphysics Scheme (WSM6)", J. Korean Meteor. Soc., 42,129-151

15. E. J. Mlawer, S. J. Taubman, P. D. Brown, M. J. Iacono and S. A. Clough, 1997, "Radiative transfer for inhomogeneous atmospheres: RRTM, a validated correlated-k model for the long wave", J. Geophys. Res., 102D, 16663-16682

16. J. Dudhia, 1989, "Numerical study of convection observed during the Winter Monsoon Experiment using a mesoscale two dimensional model", J. Atmos. Sci.,46, 3077-3107

17. J. R. Holton, 2004, “An introduction to dynamic meteorology", Fourth Edition, International Geophysics Series, Volume 88, Chapter 9, 296-313. 